\title{
Recent Data to the Jumping Plant-lice Fauna of Hungary (Hemiptera: Psylloidea)
}

\author{
G. RIPKA ${ }^{1 *}$, GY. CSÓKA ${ }^{2}$ and L. ÉRSEK ${ }^{3}$ \\ ${ }^{1}$ National Food Chain Safety Office, Directorate of Plant Protection, Soil Conservation and Agri-environment, \\ Department of Pest Management Development and Coordination, \\ Budaörsi út 141-145, H-1118 Budapest, Hungary \\ ${ }^{2}$ National Agricultural Research and Innovation Centre, Forest Research Institute, \\ Department of Forest Protection, H-3232 Mátrafüred, Hegyalja út 18, Hungary \\ ${ }^{3}$ Agricultural Office of Györ-Moson-Sopron County, Directorate of Plant Protection and Soil Conservation, \\ Arató u. 5, H-9028 Győr, Hungary
}

(Received: 16 October 2017; accepted: 27 October 2017)

\begin{abstract}
Authors made regular insect collections between 2010 and 2017, especially on ornamental trees and shrubs, on streets, parks, in city greenery, forests, botanical gardens and private gardens, in various localities of Hungary. Trioza soniae Rapisarda, 1994 and Trioza scottii Löw, 1880 are reported for the first time in Hungary. New host, locality and habitat data are given.
\end{abstract}

Keywords: Triozidae, Quercus cerris, ×Mahoberberis neubertii, Psyllidae, Laburnum watereri, forest, Hungary.

Psyllids or jumping plant-lice (Hemiptera: Psylloidea) are small plant-sap sucking insects. Their larval stages are generally host-specific (Hodkinson, 2009; Drohojowska and Burckhardt, 2014). They predominantly develop on perennial dicotyledonous angiosperms. There are only a few psyllids associated with monocots, such as the holarctic genus Livia. The psyllid fauna of Hungary is only incompletely known. So far, out of the c. 3,900 described species worldwide ( $\mathrm{Li}, 2011$ ), a total of 76 psyllid species have been recorded in the territory of Hungary (Ripka, 2008, 2009). The family Triozidae is a species-rich, probably monophyletic family. The artificially large genus Trioza Foerster, 1848 comprises a large number of morphologically very similar species with numerous convergences. In Europe, the genus Trioza is represented by 64 species (Burckhardt, 2007). Up until now, 12 Trioza species have been recorded in the Hungarian psylloid fauna, which are associated with 10 dicotyledonous families (Ripka, 2008, 2009). Previous records of Trioza ilicina (De Stefani Perez, 1901) from Hungary are misidentifications of T. soniae Rapisarda, 1994.

\footnotetext{
* Corresponding author; e-mail: RipkaG@nebih.gov.hu
} 


\section{Materials and Methods}

Ripka and Csóka (2016) recently recorded the Quercus-feeding Trioza ilicina (De Stefani Perez, 1901) as new to the fauna of Hungary. Unfortunately, the senior author misidentified Trioza soniae Rapisarda, 1994 as T. ilicina. Therefore it represents a misidentification. After a thorough re-examination of the references and the slide mounted nymphs, all specimens are Trioza soniae.

Plant samples from different trees were collected in plastic bags during the growing season between 2010 and 2017. All the plant material was examined with binocular stereomicroscope (Zeiss Stemi 2000-C) (upper and lower surfaces of the leaves, petioles, buds, bark, flowers, galls, etc.). The immatures of psyllids found on the plant samples were put directly into lactic acid. After clearing the specimens in lactic acid (for 2-4 weeks at room temperature to the desired extent), they were placed into Keifer's F-medium (Keifer, 1975). The slide preparations were dried (for 2-4 weeks) at room temperature, and then sealed with commercial nail varnish (Upton, 1991). Specimens were examined with a phase-contrast microscope (Nikon Eclipse E600). Pictures (Figs 5-8 and 15-19) were taken with a digital camera (Leica DFC 450) attached to a phase-contrast microscope (Nikon Eclipse E600). Only the focused parts of some pictures taken from the same specimen were selected and consolidated all together in a unique image giving a bi-dimensional aspect. The pictures were treated by means of Leica Application Suite (LAS) V4.4.0. The classification follows that of Burckhardt and Ouvrard (2012) and Ouvrard (2014). Morphological terminology mostly follows Ossiannilsson (1992) and Rapisarda (1994). For determination, the works of Conci and Tamanini (1985) and Rapisarda (1994) were used.

The scientific name of host plants is used according to Király (2009) and The Plant List (2013).

\section{Results}

Fam. Triozidae Löw, 1879

Trioza soniae Rapisarda, 1994

Geographical distribution - It is a Mediterranean species, reported from Italian mainland and Sicily (Rapisarda, 1994; Burckhardt, 2007; Ouvrard, 2014).

Host plant - Turkey oak, Quercus cerris L. (Fagaceae).

Immatures - Body length: $1.56-1.78 \mathrm{~mm}$, body width: $1.22-1.30 \mathrm{~mm}$. T. soniae possesses numerous, strong lanceolate setae dorsally, in constant position (Rapisarda, 1994). The Quercus-feeding T. remota lacks lanceolate setae, which are replaced by short and thin single setae dorsally. The marginal ringed sectasetae in $T$. soniae are longer, pointed. $T$. remota has distinctly truncate sectasetae. Nymphs of $T$. soniae live in small pit galls on the underside of the leaves (Rapisarda, 1994; Hodkinson, 2009). 
Adult - Head and thorax orange coloured, abdomen green. Femora and tibiae orange coloured, tarsi brownish. Length of males 3.6-3.8 mm, of females 3.8-4.0 mm (Rapisarda, 1994).

Life cyle - According to Rapisarda (1994), it has one generation. Adults overwinter on coniferous shelter plants (Rapisarda, 1994; Hodkinson, 2009). Adults return in late spring.

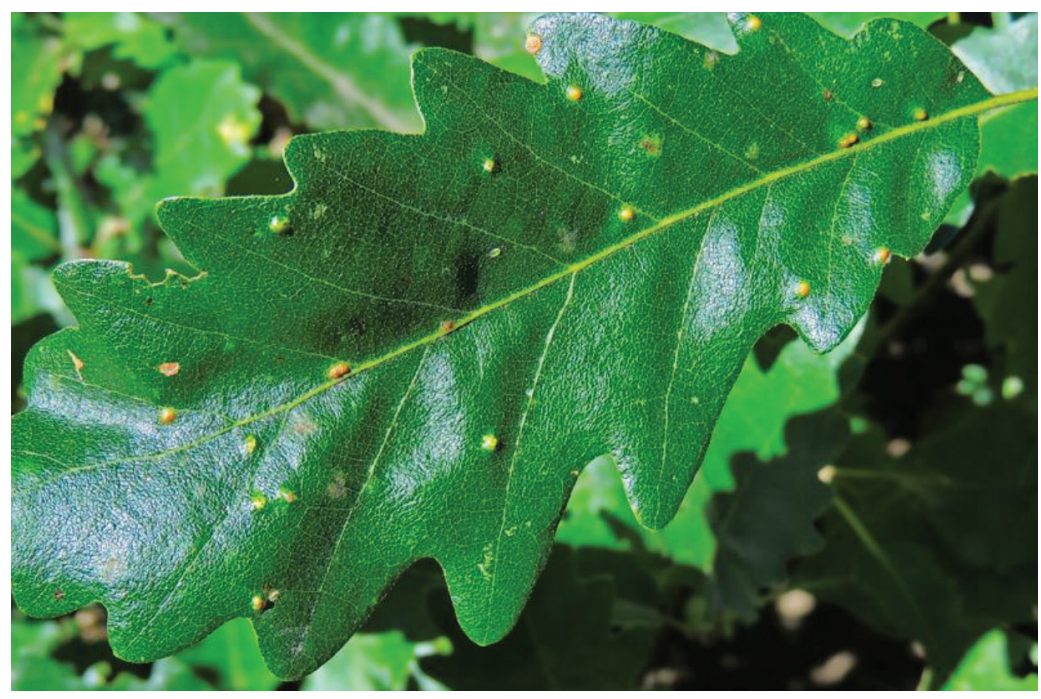

Fig. 1. Pit galls caused by Trioza soniae on the upper side of the leaf of Quercus cerris (Photo: L. Érsek)

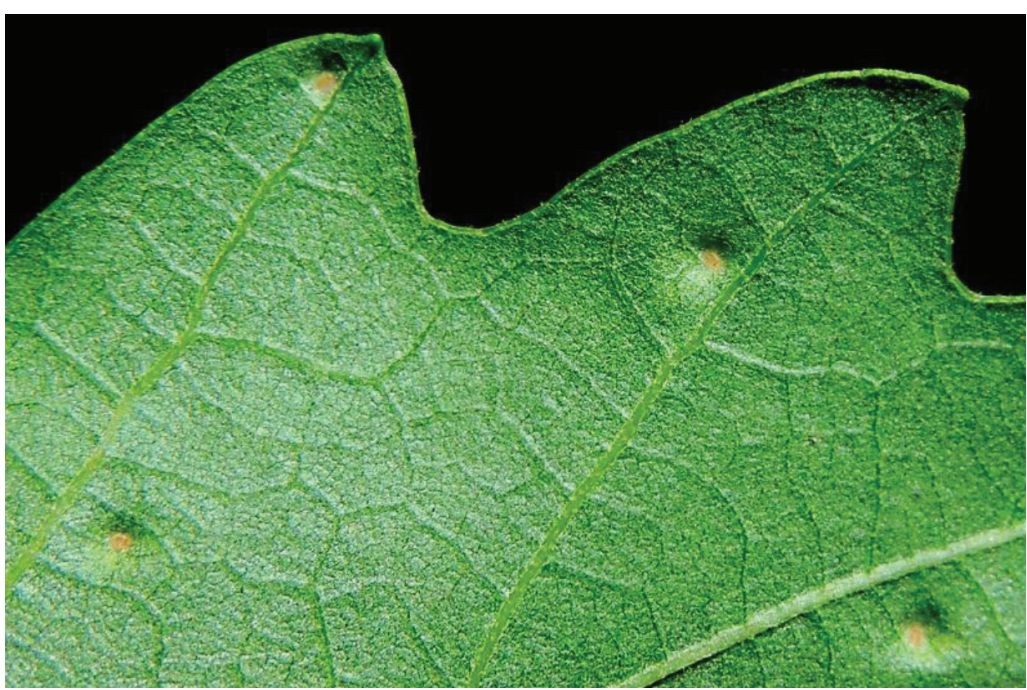

Fig. 2. Pit galls caused by Trioza soniae on the lower side of the leaf of Quercus cerris (Photo: L. Érsek) 
Hungarian data - The eggs, larvae and nymphs were collected from the lower side of the leaves of Quercus cerris L.. The young larvae are shiny yellow, dirty yellow with red eyes, while the dorsal side of developed nymph is turquoise and ventrally yellowish. Around the egg and nymph, small light green, then yellowish green, later reddish round galls on the upper side, $1-1.5 \mathrm{~mm}$ in diameter, and small concave surface, a small pit on the lower side of the leaves (Figs 1-4). The pit galls are similar to that of caused by T. ilicina.

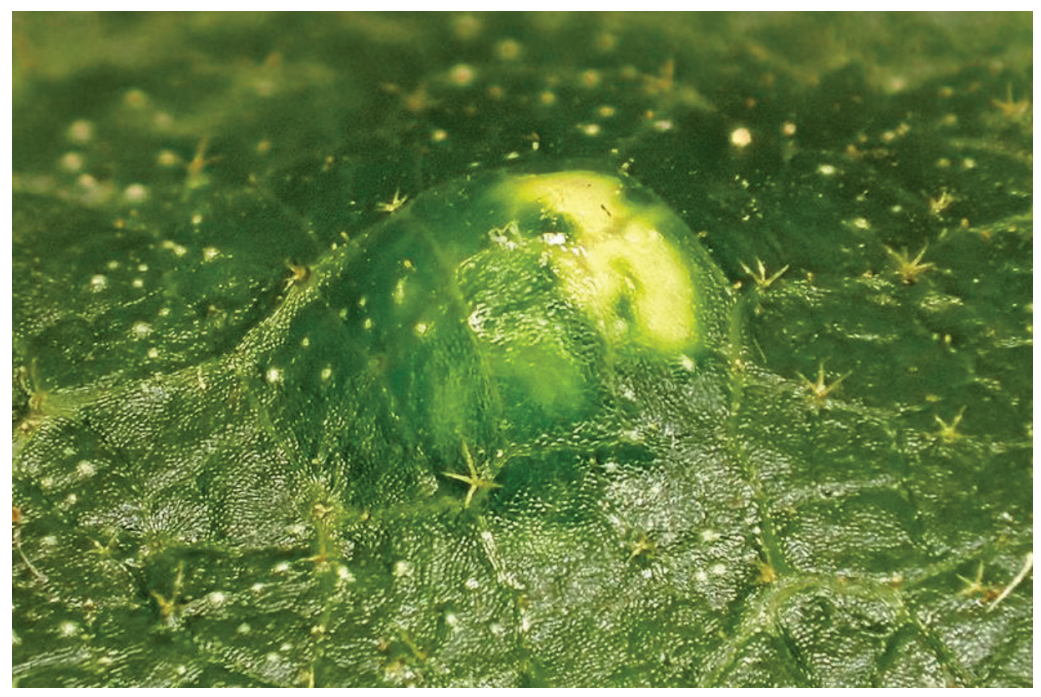

Fig. 3. Gall caused by Trioza soniae on the leaf upper side of Quercus cerris (Photo: L. Érsek)

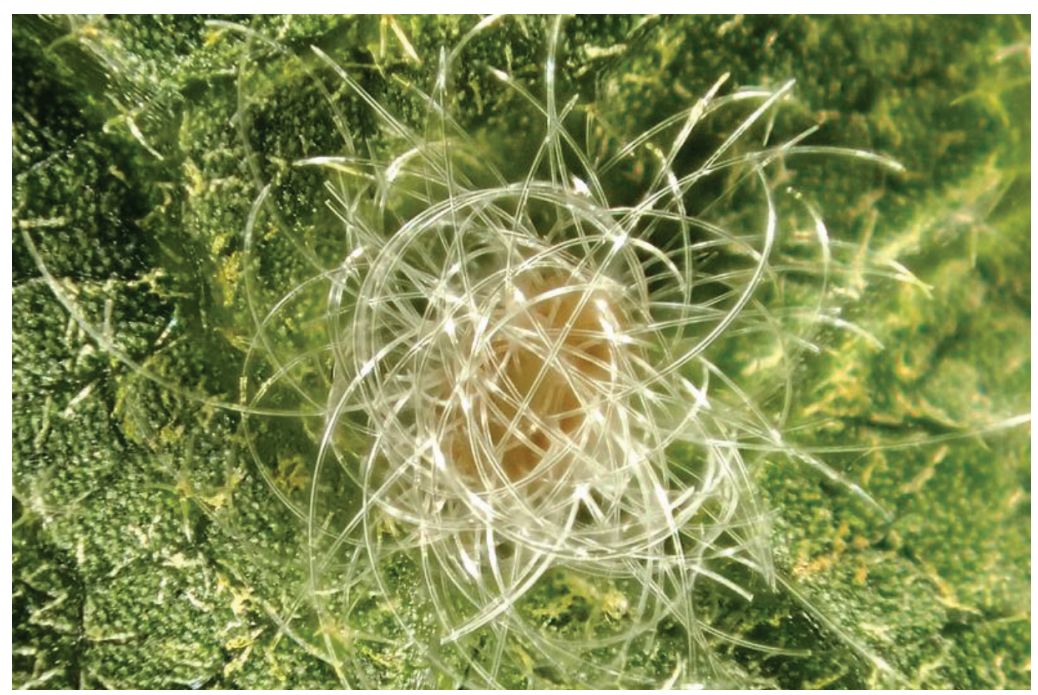

Fig. 4. Trioza soniae nymph on the leaf under side of Quercus cerris (Photo: L. Érsek) 


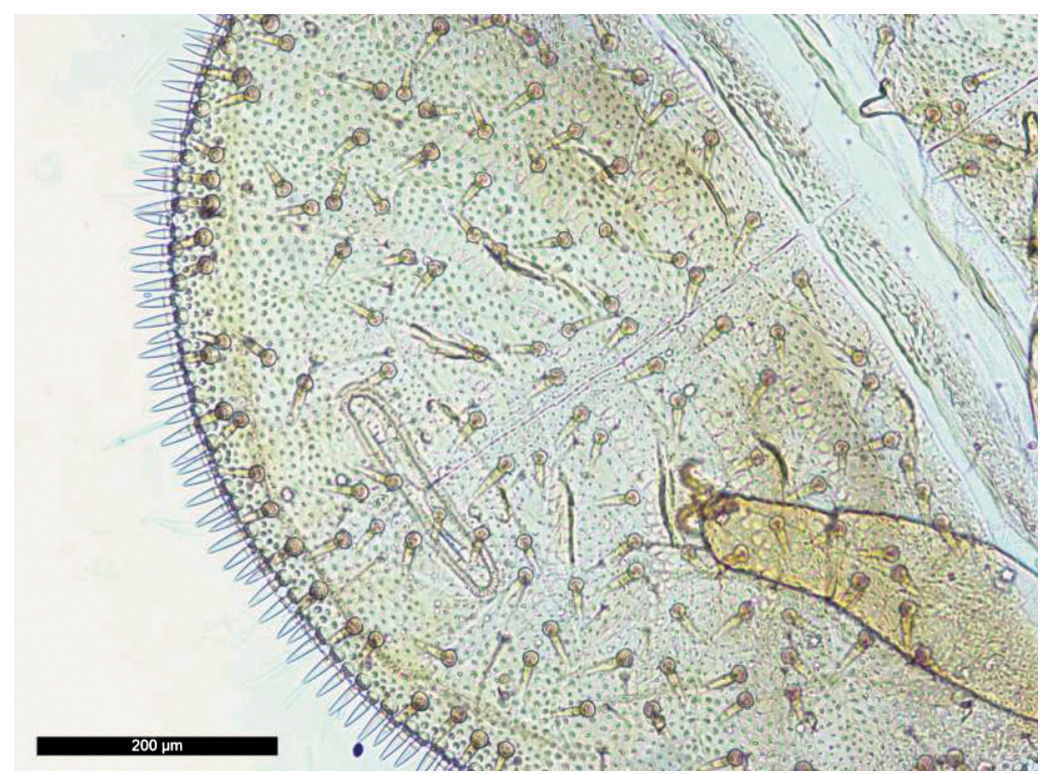

Fig. 5. Dorsal side of Trioza soniae nymph (Photo: M. Bozsó)

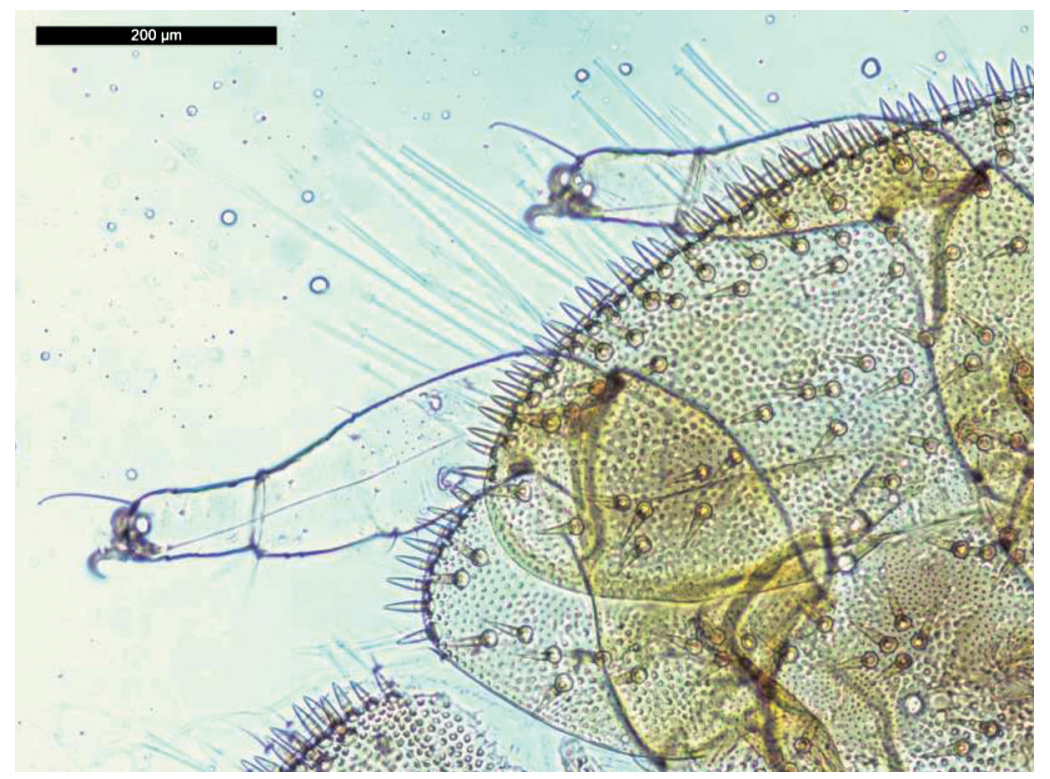

Fig. 6. Forewing pad, hindwing pad, leg 2 and leg 3 of Trioza soniae nymph (Photo: M. Bozsó) 
Some morphological charecteristics and morphometric data of the fifth instar nymphs (Figs 5-8) are as follows:

Body length $1.22-1.73 \mathrm{~mm}$, width $0.80-1.38 \mathrm{~mm}$, body length ratio: $0.72-0.81$. Head margin (HSS) with 20-29 pointed and slightly ringed sectasetae per each side, borne on short protuberances. Antennae ventral, seven-segmented, 122-320 $\mu \mathrm{m}$ long, with two blunt and one pointed setae distally. Forewing pad margin (FWSS) and hindwing pad margin (HWSS) with 34-73 and 6-8 pointed and slightly ringed sectasetae, respectively. Abdomen (ASS) with 34-55 pointed and slightly ringed sectasetae per each side. Length of marginal pointed sectasetae $25-40 \mu \mathrm{m}$. All dorsal sclerites and wing pads covered with pointed and slightly ringed sectasetae, 23.5-42.5 $\mu \mathrm{m}$ long. Each marginal sectaseta produces a long, pointed and hyaline wax filament or pipe, which partly remained in the microscopical preparations after the clearing procedure. These copious wax filaments of nymphs provide defence against desiccation, also predators and parasitoids. Dorsal cuticule densely covered with fine tubercles. Sectasetae completely absent from ventral surface. Only simple, slender and pointed setae and tiny spinules forming transverse bands on each abdominal segment ventrally. Anal pore entirely ventral, surrounded by two simple rings of circumanal pores. The outer ring is flat rectangle, 25-45 long in the middle, and 162-245 wide, formed by densely arranged elliptic, oblong, close cells. The inner one is formed by smaller, roundish cells, in an irregular row which is double in some zones. Each tarsus with a flabellate arolium, a pair of developed claws and a long capitate seta distally.

Locality and date - Turkey oak, Quercus cerris: Vászoly, Veszprém county, in seminatural habitat, $21^{\text {th }}$ August 2010, coll. G. Ripka; Cserépfalu, Borsod-Abaúj-Zemplén county, in a wooded pasture, $9^{\text {th }}$ September 2015, coll. Gy. Csóka; Mátrafüred, Heves county, in a middle age open forest, $14^{\text {th }}$ September 2015, coll. Gy. Csóka.

Remarks - Horváth $(1886,1897)$ did not record it from the Austro-Hungarian Monarchy. This species is new for the Hungarian fauna. The new Hungarian locations listed above are many hundred kms further North from the native range of $T$. soniae has been known so far. Therefore these records can be considered as results of a significant northward move of the species.

\section{Key to fifth instar nymphs of species Trioza Foerster known from the West Palaearctic species of the genus Quercus L.}

1 Nymphal margin with truncate sectasetae .................................................. 2

- Nymphal margin with pointed sectasetae .......................................................... 3

2 Dorsum with stout and well discernible nearly pointed sectasetae, 25-40 $\mu \mathrm{m}$ long. Marginal truncate sectasetae arranged as follows: HSS : 15-21; FWSS: 38-53; ASS: 30-50. On Q. ilex L............................................................ T. ilicina (De Stefani Perez)

- No stout and well discernible nearly pointed sectasetae on the dorsum, where only small (10-15 $\mu \mathrm{m})$ truncate sectasetae occur. Marginal truncate sectasetae arranged as 


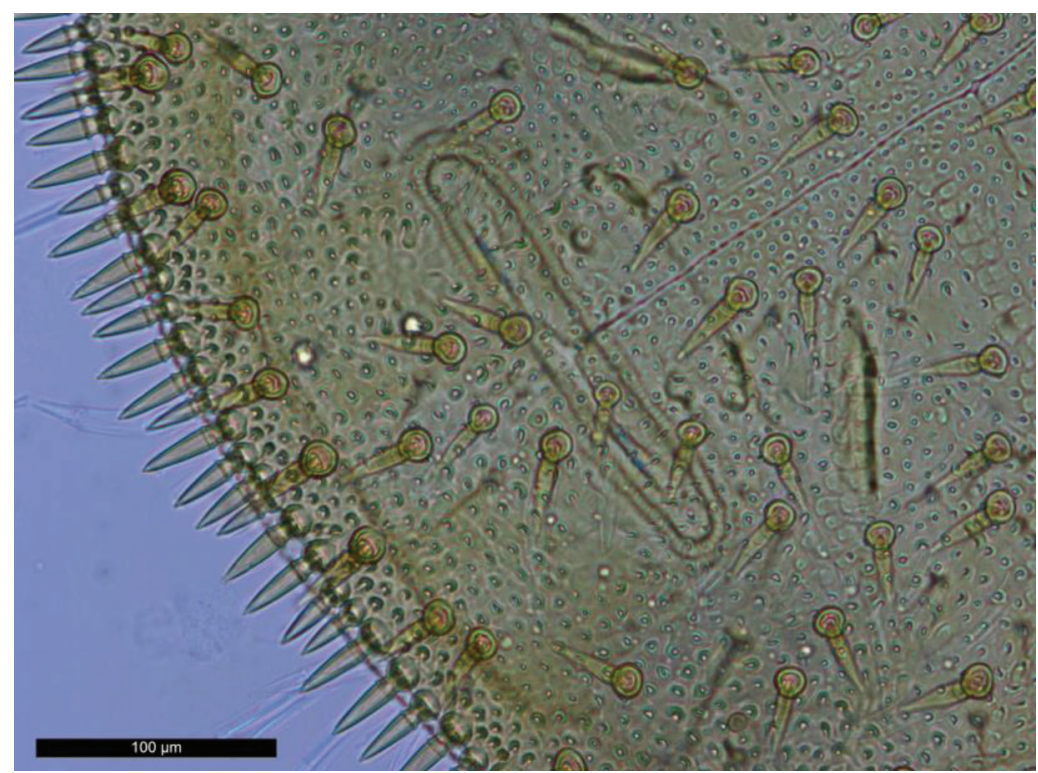

Fig. 7. Abdomen of Trioza soniae nymph with marginal pointed sectasetae (Photo: M. Bozsó)

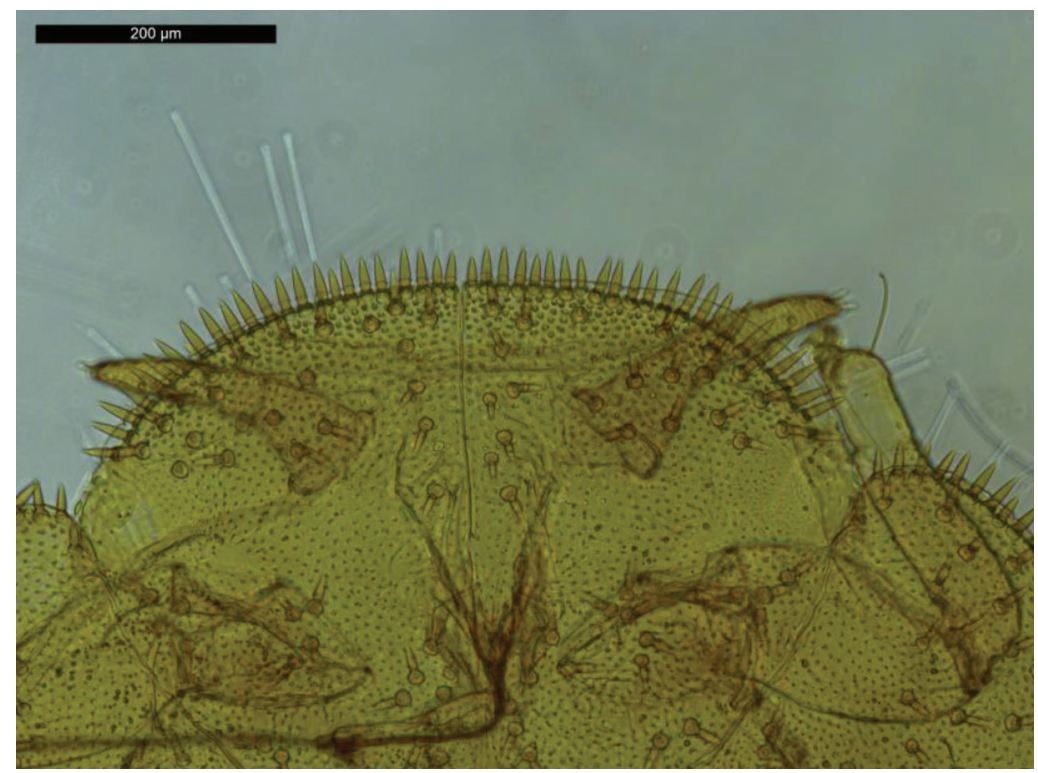

Fig. 8. Head of Trioza soniae nymph with antennae, rostrum (proboscis) and leg 1 (Photo: M. Bozsó) 
follows: HSS: 25-41; FWSS: 68-105; ASS: 58-93. On various Quercus spp., Q. robur L., Q. petraea (Mattuschka) Liebl. T. remota Foerster

3 Dorsum covered with stout and pointed sectasetae, 30-45 $\mu \mathrm{m}$ long. Marginal pointed sectasetae arranged as follows: HSS: 17-25, (Hungarian population 20-29); FWSS: 51-64, (Hungarian population 34-73); ASS: 39-51, (Hungarian population 34-55). On $Q$. cerris L T. soniae Rapisarda

- No sectasetae but only simple setae on the dorsum. Marginal pointed sectasetae arranged as follows: HSS : 25-32; FWSS: 62-72; ASS: 53-60.

On Q. trojana Webb. T. apulica Rapisarda

Trioza scottii Löw, 1880

Geographical distribution - It is a European species, reported from Austria, former Czechoslovakia, France mainland, Germany, Italy mainland, Switzerland, former Yugoslavia, Slovenia, former USSR, Caucasia, Algeria, Iran and Turkey (Lauterer, 1977; Gegechkori, 1984; Seljak, 2006; Burckhardt, 2007; Ouvrard, 2014).

Host plants - barberry, Berberis L.; European barberry, Berberis vulgaris L., Berberis iberica Stev. et Fisch. ex DC (Berberidaceae) (Gegechkori, 1984; Hodkinson, 2009; Ouvrard, 2014).

Immatures - They live in small pit galls (Hodkinson, 2009).

Adult - According to the original description (Löw, 1880), head and thorax pale clay-yellow sometimes with diffuse brown or reddish brown markings. Abdomen pale yellow or greenish ventrally, dorsally with broad brown or blackish-brown stripes, and with reddish membrane. Vertex 1.5 times longer than half width, flat, with two shallow brownish red or brown discal impressions and black, anteriorly incised median suture. Eyes dark reddish brown, ocelli red. Genal cones brown or black, evenly tapering from wide base, pointed, slightly divergent, inclined downwards, slightly longer than the half length of vertex. First three segments of antennae are yellow, with dark distal end, the others are blackish brown. Antennal segment III 1.3-1.5 times longer than segment IV. Forewings 2.5 times longer than broad, widest at middle part, almost transparent (clear), hyaline, veins yellow. Legs pale clay-yellow, tinted with light brown lines. Tarsi fuscous or blackish-brown. Male's genital plate brown, that of female pale yellow or greenish (Löw 1880). Length of males and females 2.0-2.25 mm (Löw, 1880).

Life cyle - According to Hodkinson (2009), it has one generation. Adults overwinter on conifers (Hodkinson, 2009).

Hungarian data - The yellowish white eggs, white larvae and yellowish nymphs were collected from the lower side of the leaves of hybrid mahonia or mahoberberis, $\times$ Mahoberberis neubertii (hort. ex Lem.) C.K. Schneid. (Berberidaceae), which is a new host plant. Around the egg, larvae and nymph, small galls on the upper side, and small concave surface, a small pit on the lower side of the leaves (Figs 9-14).

Some morphological charecteristics and morphometric data of the nymphs (Figs 15-19) are as follows:

Body length $0.52-0.55 \mathrm{~mm}$, width $0.38-0.43 \mathrm{~mm}$, body length ratio: $0.71-0.77$. Head margin (HSS) with 39-46 truncate and ringed sectasetae, borne on short protuber- 


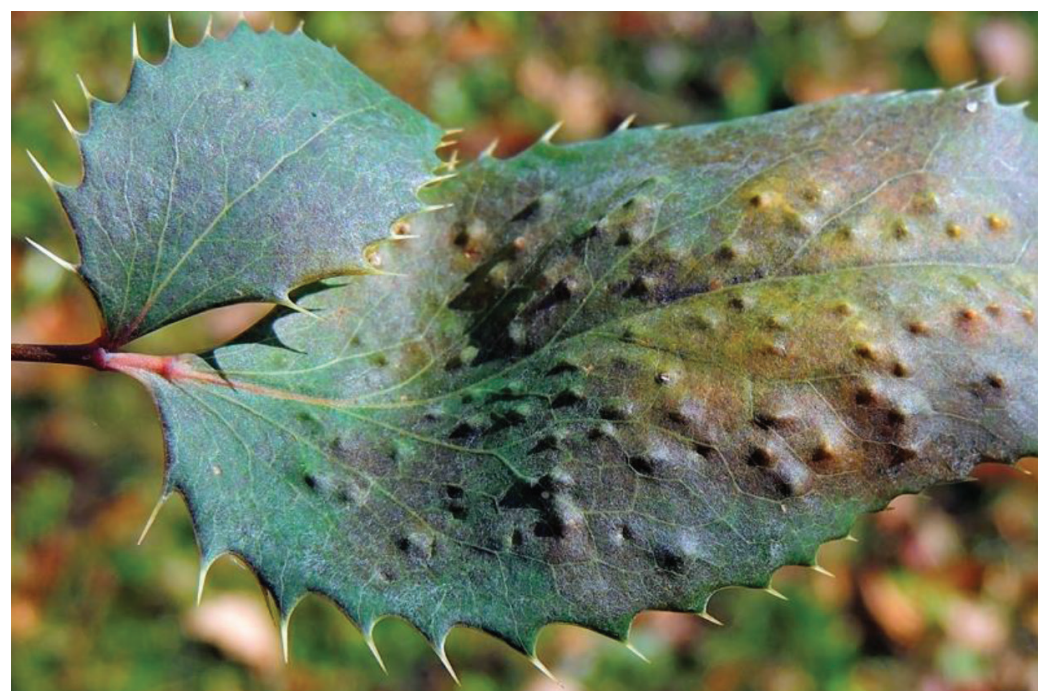

Fig. 9. Pit galls caused by Trioza scottii on the upper side of the leaf of $\times$ Mahoberberis neubertii (Photo: L. Érsek)

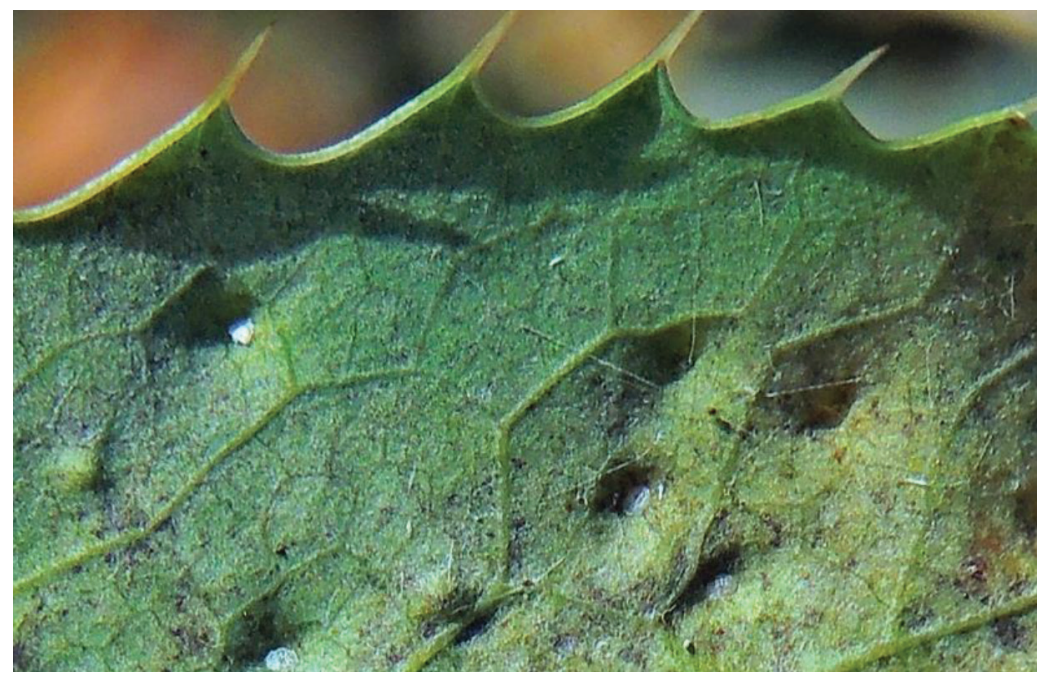

Fig. 10. Pit galls caused by Trioza scottii on the lower side of the leaf of $\times$ Mahoberberis neubertii (Photo: L. Érsek) 


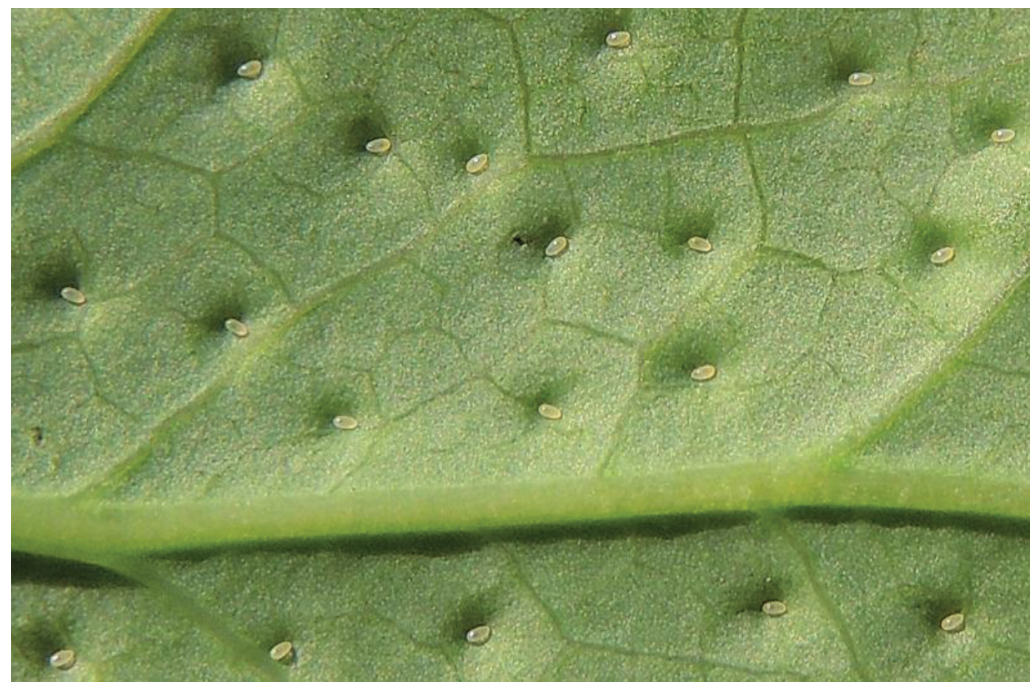

Fig. 11. Eggs of Trioza scottii on the leaf under side of $\times$ Mahoberberis neubertii (Photo: L. Érsek)

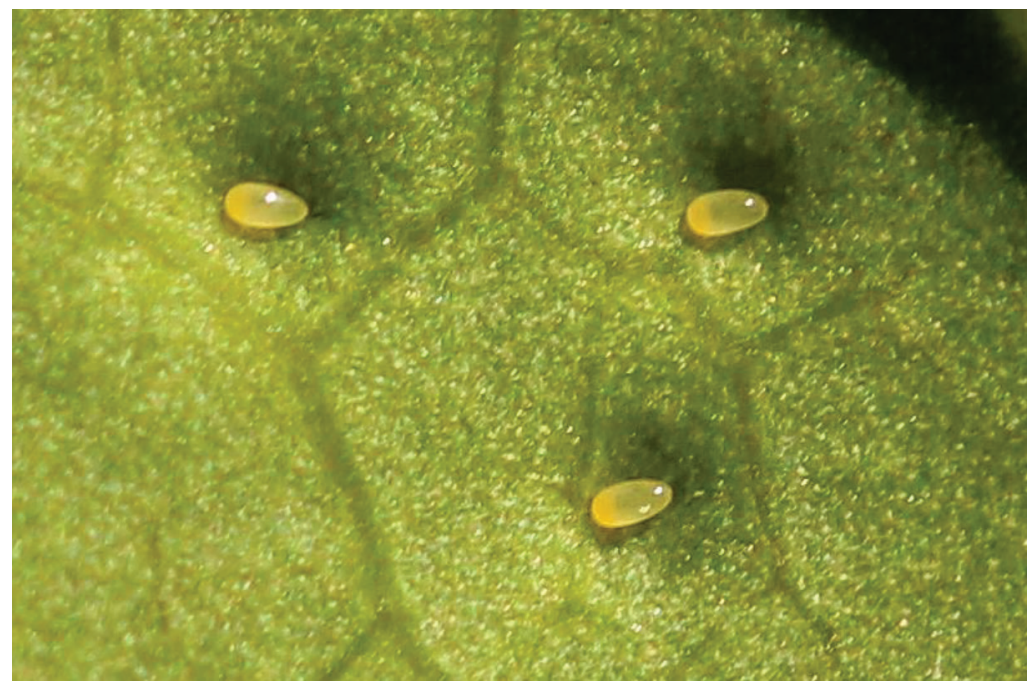

Fig. 12. Eggs of Trioza scottii on the leaf under side of $\times$ Mahoberberis neubertii (Photo: L. Érsek) 


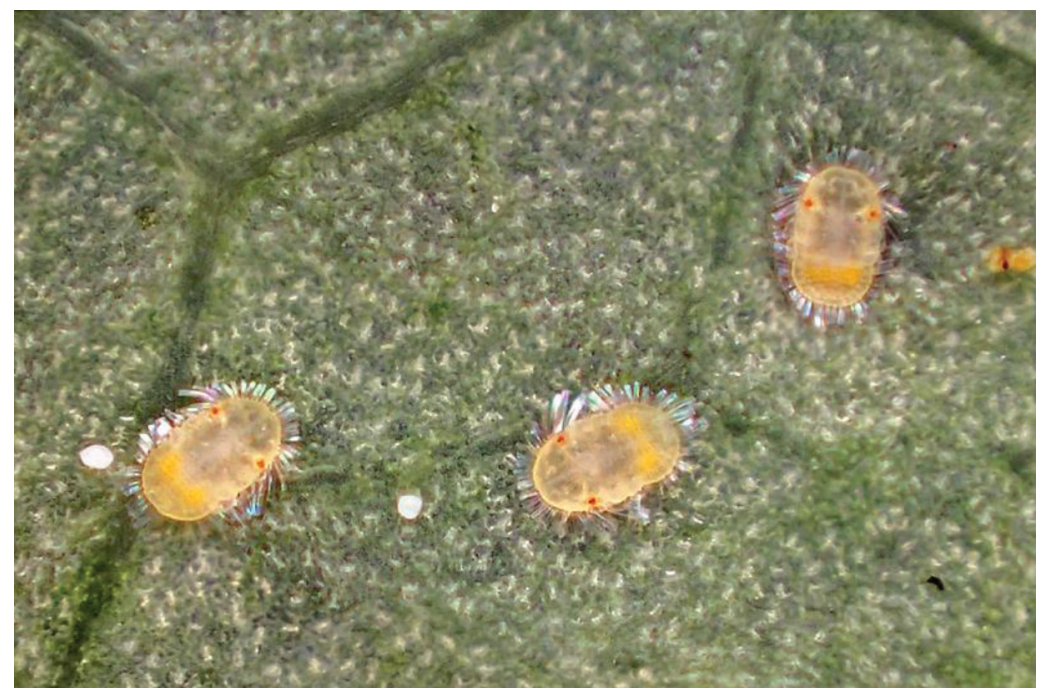

Fig. 13. Trioza scottii nymphs (Photo: L. Érsek)

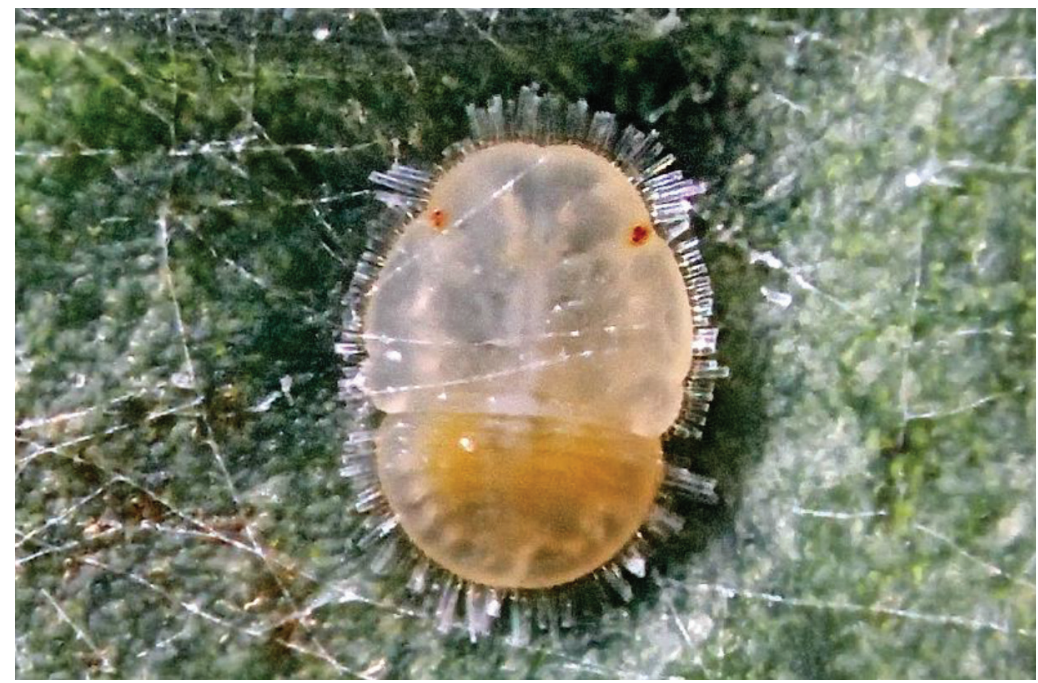

Fig. 14. Trioza scottii nymph (Photo: L. Érsek) 


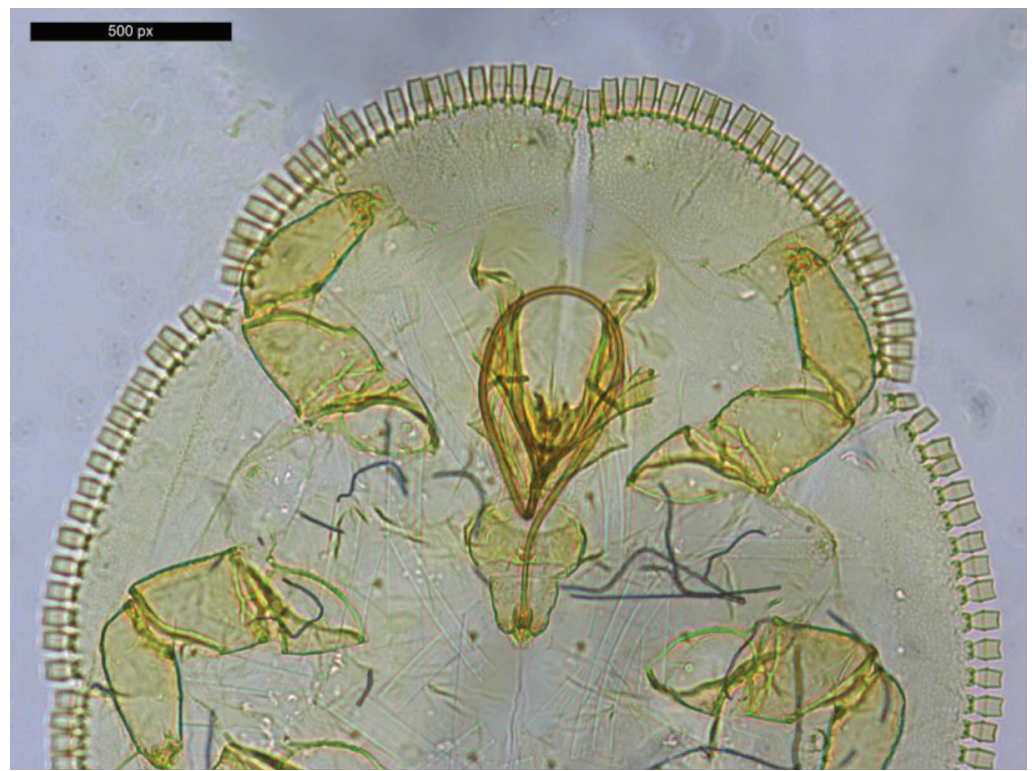

Fig. 15. Head and thorax of Trioza scottii nymph with marginal truncate sectasetae (Photo: M. Bozsó)

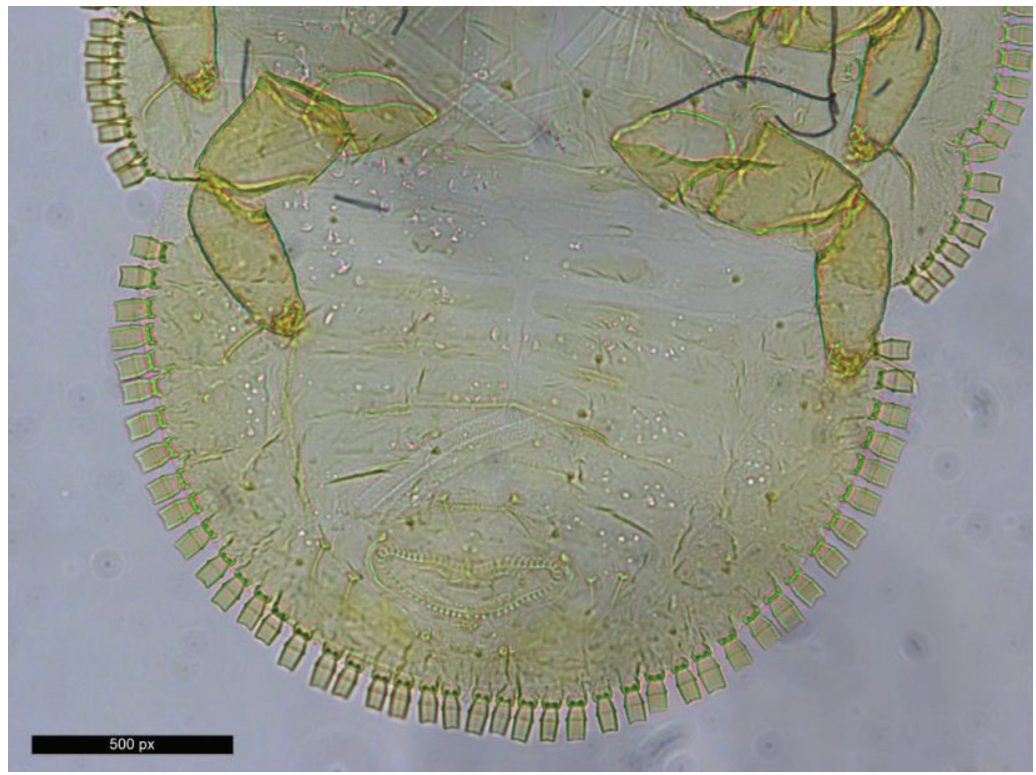

Fig. 16. Abdomen of Trioza scottii nymph with marginal truncate sectasetae (Photo: M. Bozsó) 


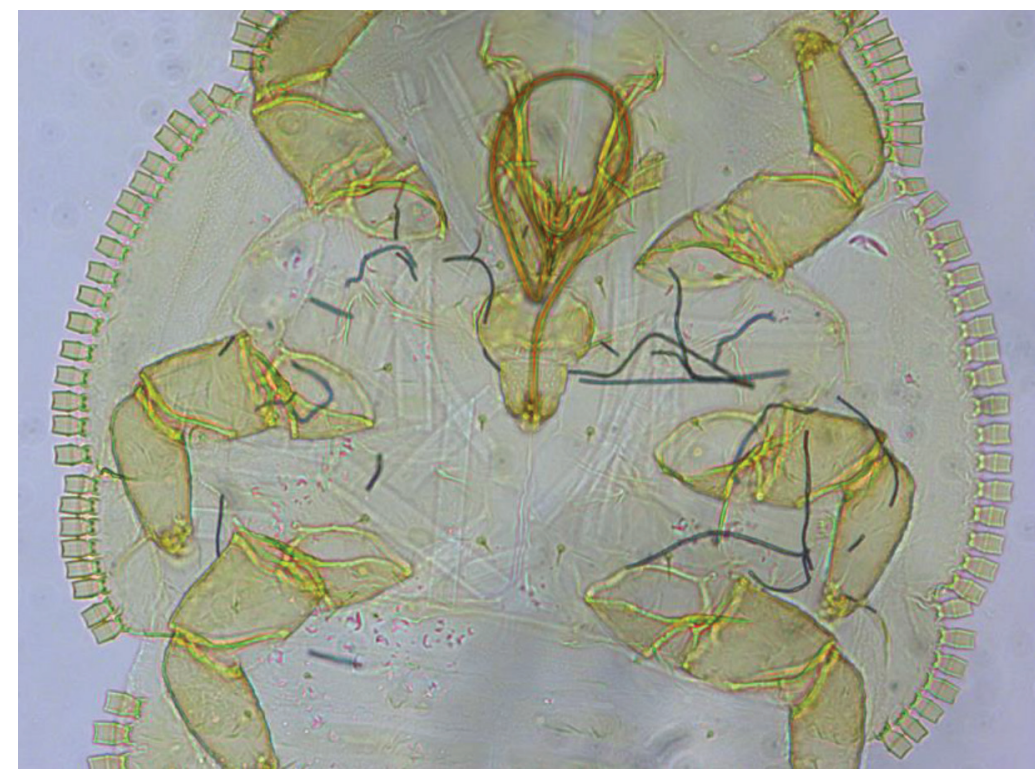

Fig. 17. Forewing pad and hindwing pad of Trioza scottii nymph with marginal truncate sectasetae (Photo: M. Bozsó)

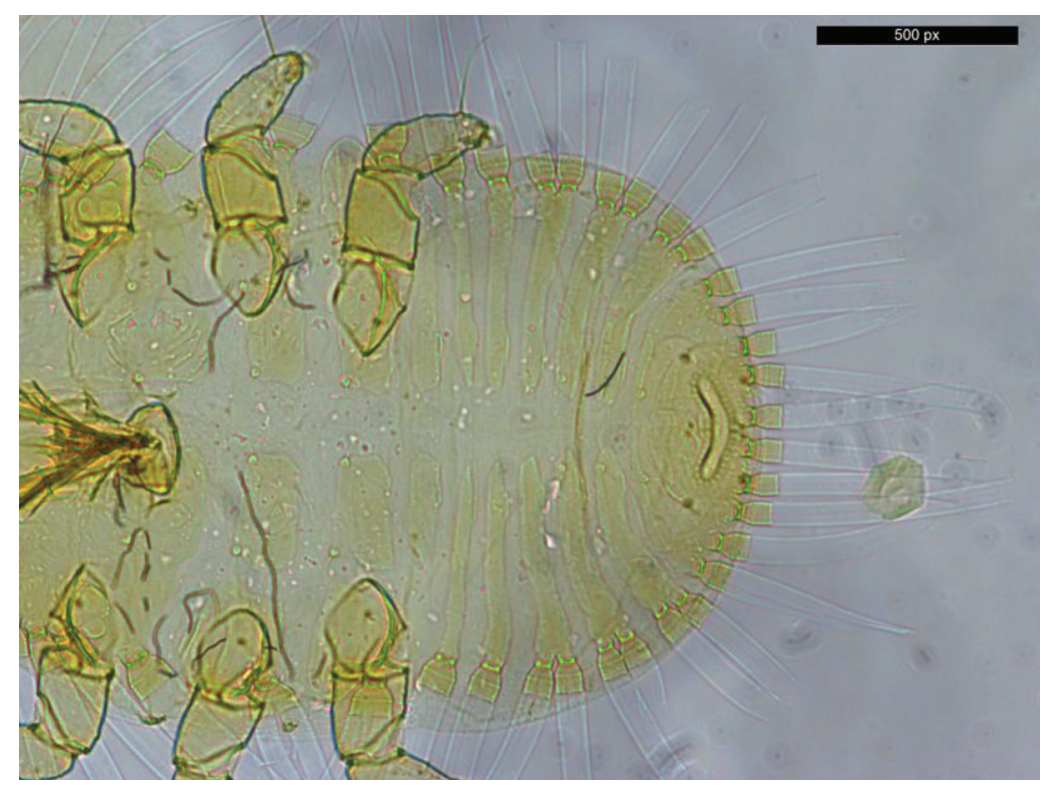

Fig. 18. Thorax and abdomen of Trioza scottii larva with marginal truncate sectasetae (Photo: M. Bozsó) 


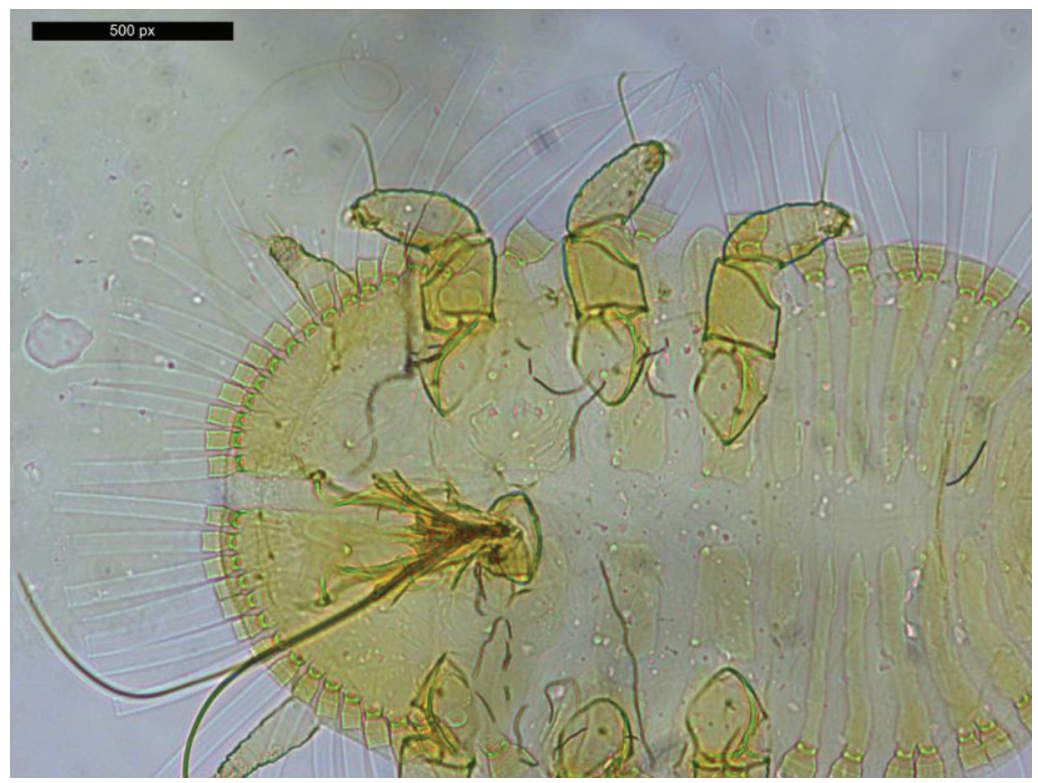

Fig. 19. Head and legs of a Trioza scottii larva with marginal truncate sectasetae (Photo: M. Bozsó)

ances. Antennae on ventral surface of the head, 63-68 $\mu \mathrm{m}$ long, with two blunt setae distally. Forewing pad margin (FWSS) and hindwing pad margin (HWSS) with 14-19 and 5-8 truncate and ringed sectasetae, respectively. Abdomen margin (ASS) with 43-46 truncate and ringed sectasetae. Length of marginal sectasetae 10-17 $\mu \mathrm{m}$. All marginal ringed sectasetae concave distally. Each marginal ringed sectaseta produces a pointed and hyaline wax filament. These wax filaments protect the nymphs against desiccation, predators and parasitoids. Sectasetae completely absent from dorsum and venter. Dorsal surface with simple and pointed setae and irregular dashes and short dashes in row on the rear margin of abdominal segments. Ventral cuticle with simple, slender and pointed setae, and tiny dots. The simple and pointed setae on the dorsum and venter 3-14 $\mu \mathrm{m}$ and 5-35 $\mu \mathrm{m}$ long, resp. Anus situated ventrally, circumanal pore-ring broad and shallowly V-shaped, with two simple rings of circumanal pores. Cells of outer ring anteriorly are slightly larger and more elongate oval than that of posteriorly, which are globoid. The outer circumanal pore-ring is $18-24 \mu \mathrm{m}$ long in the middle, and $72-88 \mu \mathrm{m}$ wide. The inner one is formed by smaller and roundish cells in an irregular row which is interrupted in some zones. Each tarsus with a half circle arolium, a pair of undeveloped smaller claws and a long capitate seta distally.

Locality and date - hybrid mahonia or mahoberberis, $\times$ Mahoberberis neubertii (hort. ex Lem.) C. K. Schneid., Budapest, district XI, Botanical Garden of Szent István University, $9^{\text {th }}$ May 2017, coll. G. Ripka; the same locality, $25^{\text {th }}$ May 2017, coll. L. Érsek.

Remarks $-T$. scottii has not been recorded from Hungary, therefore it is a new species in the Hungarian fauna. 
Further new Hungarian psyllid records are as follows:

Livilla variegata (Löw, 1881). Host plant: golden chain tree, bean tree or Voss's laburnum, Laburnum watereri (Wettst.) Dippel. Budapest, district XI, Botanical Garden of Szent István University, 25 ${ }^{\text {th }}$ May 2017, coll. L. Érsek. Eggs and larvae were found on the lower side of the leaflets. In Hungary it was previously recorded from Laburnum anagyroides Medik. (Ripka, 1997).

Trioza neglecta Loginova, 1978. Host plant: silverberry or oleaster, Elaeagnus sp. Budapest, district XI, Botanical Garden of Szent István University, 25 ${ }^{\text {th }}$ May 2017, coll. L. Érsek. Larvae were found on the underside of the leaves. This species was also reported from Hungary (Ripka, 1997).

\section{Acknowledgement}

The authors would like to thank Dr. Miklós Bozsó (National Food Chain Safety Office, Budapest) for his assistance in taking microphotos.

\section{Literature}

Burckhardt, D. (2007): Fauna Europaea: Psylloidea. Fauna Europaea version 1.3., Taxon Details. Available from http://www.faunaeur.org [accessed 7 June 2017]

Burckhardt, D. and Ouvrard, D. (2012): A revised classification of the jumping plant-lice (Hemiptera: Psylloidea). Zootaxa, 3509, 1-34.

Conci, C. and Tamanini, L. (1985): Redescription of Trioza ilicina (De Stefani Perez, 1901) comb. n., from Quercus ilex (Homoptera Psylloidea). Boll. Lab. Entomol. Agrar. Filippo Silvestri, Portici. 42, 33-46.

Drohojowska, J. and Burckhardt, D. (2014): The jumping plant-lice (Hemiptera: Psylloidea) of Turkey: a checklist and new records. Turkish J. Zoology, 38, 559-568.

Gegechkori, A. M. (1984): Pszillidy (Homoptera, Psyllodea) Kavkaza. Akademija NAUK Gruzinszkoj SzSzR. Mecniereba, Tbiliszi, 1-296.

Hodkinson, I. D. (2009): Life cycle variation and adaptation in jumping plant lice (Insecta: Hemiptera: Psylloidea): a global synthesis. J. Natural History, 43, 65-179. Available from DOI: 10.180/00222930802354167 [accessed 28 December 2015]

Horváth, G. (1886): A magyarországi Psyllidákról. (On the psyllids of Hungary.) Mathematikai és Természettudományi Közlemények, 21, 292-320.

Horváth, G. (1897): Ordo. Hemiptera. In: A Magyar Birodalom Állatvilága (Fauna Regni Hungariae). III. Arthropoda. (Insecta. Hemiptera.) Királyi Magyar Természettudományi Társulat, Budapest, 72 p.

Keifer, H. H. (1975): Eriophyoidea Nalepa. In: L. R. Jeppson, H. H. Keifer and E. W. Baker (eds): Mites Injurious to Economic Plants. University of California Press, Berkeley, Los Angeles, London. pp. 327-533.

Király, G. (ed. 2009): Új magyar füvészkönyv. Magyarország hajtásos növényei. Határozókulcsok. [New Hungarian Herbal. The Vascular Plants of Hungary. Identification key.] Aggteleki Nemzeti Park Igazgatóság, Jósvafö. 616 p.

Lauterer, P. (1977): Psyllodea, Psylloidea. Enumeratio insectorum Bohemoslovakiae. Check list 1. Tschechlosowakische Insektenfauna. Acta faunistica entomologica Musei Nationalis Pragae 15 (Supplementum 4), 97-100.

Li, F. (2011): Psyllidomorpha of China (Insecta: Hemiptera). Science Press, Beijing, China, i-xli, 1976 pp+ 19 plates (in Chinese with English summary)

Löw, F. (1879): Zur systematik der Psylloden. Verhandlungen der kaiserlich-königlichen Zoologisch-botanischen Gesellschaft in Wien, 28, 585-610. 
Löw, F. (1880): Mittheilungen über Psylloden. Verhandlungen der kaiserlich-königlichen Zoologisch-botanischen Gesellschaft in Wien, 29, 549-598.

Ossiannilsson, F. (1992): The Psylloidea (Homoptera) of Fennoscandia and Denmark. In: Fauna Entomologica Scandinavica, Vol. 26. E. J. Brill, Leiden-New York-Köln, 347 p.

Ouvrard, D. (2014): Psyl'list - The World Psylloidea Database. http://www.hemiptera-databases.com/psyllist. DOI: 10.5519/0029634 [accessed 19 April 2017]

Rapisarda, C. (1994): Trioza soniae and T. apulica n. spp., on Quercus spp., from Southern Italy. Memorie della Società entomologica italiana, Genova. 72, 175-188.

Ripka, G. (1997): Recent data to the psyllid fauna of ornamental trees and shrubs of Hungary (Homoptera: Psylloidea). (Újabb adatok a díszfa- és díszcserjefajok levélbolha-faunájának ismeretéhez (Homoptera, Psylloidea).) Növényvédelem, 33, 269-273.

Ripka, G. (2008): Checklist of the Psylloidea of Hungary (Hemiptera: Sternorrhyncha). Acta Phytopathol. et Entomol. Hung. 43, 121-142.

Ripka, G. (2009): Additional data to the aphid and psylloid fauna of Hungary (Hemiptera: Sternorrhyncha). Acta Phytopathol. et Entomol. Hung. 44, 397-417.

Ripka, G. and Csóka, Gy. (2016): New records of jumping plant-lice from Hungary (Hemiptera: Psylloidea). Acta Phytopathol. et Entomol. Hung. 51, 219-227.

Seljak, G. (2006): An overview of the current knowledge on the jumping plant-lice of Slovenia (Hemiptera: Psylloidea). Acta Entomologica Slovenica, 14, 11-34.

The Plant List (2013): Version 1.1 Published on the Internet; http://www.theplantlist.org/ (September 2013) [accessed 23 June 2017]

Upton, M. S. (1991): Methods for Collecting, Preserving, and Studying Insects and allied forms. The Australian Entomological Society, Brisbane. Misc. Publ. No. 3. v +86 p. 